\title{
Clostridium perfringens Type A from Broiler Chicken with Necrotic Enteritis in Kashmir Valley, India
}

\author{
${\text { Q. } \text { Nyrah }^{1}{ }^{*} \text {, S.A. Wani }}^{1}$, N. Nazir ${ }^{1}$, S. Rasool ${ }^{1}$, Q. Beigh ${ }^{1}$, Z.A. Kashoo ${ }^{1}$, \\ I. Hussain ${ }^{1}$, Sabia Qureshi ${ }^{1}$ and R. Ali ${ }^{2}$ \\ ${ }^{1}$ Division of Veterinary Microbiology and Immunology, Faculty of Veterinary Sciences and \\ Animal Husbandry, SKUAST-K, India \\ ${ }^{2}$ Division of Veterinary Pathology, Faculty of Veterinary Sciences and Animal Husbandry, \\ SKUAST-K, India \\ *Corresponding author
}

\section{A B S T R A C T}

\begin{tabular}{|l|}
\hline Ke y w or d s \\
$\begin{array}{l}\text { Clostridium } \\
\text { perfringens, } \\
\text { multiplex PCR, } \\
\text { Toxin typing. }\end{array}$ \\
\hline Article Info \\
\hline $\begin{array}{l}\text { Accepted: } \\
17 \text { October } 2017 \\
\text { Available Online: } \\
10 \text { December } 2017\end{array}$ \\
\hline
\end{tabular}

The current study reports occurrence and molecular toxinotyping of Clostridium perfringens isolates in Kashmir valley. A total of 217 feacal samples and intestinal contents of broiler chickens suspected for enteritis were collected and screened for $C$. perfringens out of which $66(30.41 \%)$ were found positive using Robertson's cooked meat media and Sulphite Polymixin Sulphadiazine (SPS) agar. The isolates were confirmed by 16S rRNA gene specific PCR and analyzed by multiplex PCR for toxinotyping. All the isolates were found to harbour alpha toxin gene (cpa) of $C$. perfringens. However, 13 isolates also carried beta2 toxin gene $(c p b 2)$. None of the isolates were positive for beta $(c p b)$, epsilon ( $e t x)$, iota (itx) and enterotoxin (cpe) genes. Highest prevalence was found in chicken with age group of 2-6 weeks. Mortality ranged from 2-4 percent per day. Necropsy of chickens revealed that their intestines were dilated with inflammatory exudates and characterized by mucosal necrosis indicating Clostridium perfringens type A to be the major causative types for necrotic enteritis of broilers in Kashmir, India with significant role of alpha toxin.

\section{Introduction}

Avian necrotic enteritis (NE) caused by $C$. perfringens type $\mathrm{A}$, rod shaped, grampositive, anaerobic spore forming bacterium is wide spread in broilers imposing a significant economic burden on the poultry industry worldwide (Dahiya et al., 2006). It is an acute, often fatal, disease of chickens characterized by depression, loss of appetite and sudden death. It occurs both as an acute clinical disease and as a subclinical disease with necrosis in the intestines or as $C$. perfringens-associated hepatitic change
$(\mathrm{CPH})$ witiohepatitis or fibrinoid necrosis in the liver. In broilers, outbreaks of clinical NE have been reported from all poultry growing areas of the world (Ficken and Wages, 1997; Dahiya et al., 2006). It has also been recorded in wild geese (Wobeser and Rainnie, 1987), wild crows (Asaoka et al., 2004), ostriches (Kwon et al., 2004) and in capercaillies reared in captivity (Hofshagen and Stenwig, 1992). $C$. perfringens type A from soil, dust and contaminated feed and litter has been implicated as a source of infection (Craven et 
al., 2001). Although, more than one toxin produced by $C$. perfringens might be involved in causing NE, alpha-toxin is the most important (Al-Sheikhly and Truscott, 1977a; Al-Sheikhly and Truscott, 1977b). Later, a novel pore-forming toxin named NetB (necrotic enteritis toxin B-like) was identified in the strains of $C$. perfringens associated with NE.

Under field conditions, NE occurs in two forms: an acute clinical form and a mild subclinical form. The acute form of $\mathrm{NE}$ is characterized by visible clinical signs like watery diarrhoea and sudden increase in flock mortality but often without any premonitory signs. Birds that do not succumb to clinical signs, may develop a sub-clinical clostridial infection.

In the sub-clinical form of the disease there is often no peak mortality. Intestinal damage as a consequence of disease leads to a reduction in performance noticeable as reduced weight gain and an increased feed conversion ratio (Kaldhusdal and Hofshagen, 1992; Timbermont et al., 2010). Acute symptoms of the disease are severe depression, decreased appetite, and reluctance to move, ruffled feathers and diarrhoea (Ficken and Wages, 1997). The period of illness is usually short (1-2 hrs) and most of the birds are just found dead (Helmbold and Bryant, 1971). Birds that have died of NE have a foetid odour, are usually dehydrated with dark, dry pectoral musculature and pale kidneys (Long et al., 1974). The unopened intestinal wall is darker in colour than normal and distended due to the presence of large amounts of bile stained contents.

In an affected flock the mortality rate can be anything from $1 \%$ to as high as $50 \%$ (Craven et al., 2001). Sub-clinical NE does not manifest any clinical signs and mostly under field conditions, only detected at the processing plant(s) by the rejection of carcasses (McDevitt et al., 2006). It is usually associated with hepatitis and cholangiohepatitis.

The environment in the intestinal tract is of vital importance for the growth of $C$. perfringens and there probably has to be a disturbance in the jejunum before $C$. perfringens can start to proliferate in this part of the gut. Important factors are nutrition, $\mathrm{pH}$, oxygen and the microflora in the jejunum (Johansson, 2006). Different types of stress experienced by the birds may also cause disturbances in the gut.

The most important known predisposing factor for $\mathrm{NE}$ is damage to the intestinal mucosa, caused by coccidial pathogens. In particular, Eimeria species that colonize the small intestine, such as Eimeria maxima and Eimeria acervulina are known to predispose to necrotic enteritis (Williams et al., 2003). Present study reports the occurrence of fatal necrotic enteritis due to $C$. perfringens in broiler chicken and their virulence determinants.

\section{Materials and Methods}

\section{Sample collection}

A total of 217 samples (87 fecal materials were from live birds and 130 intestinal samples were from post mortem carcasses) with a history of sudden deaths or diarrhoea were collected from organized farms such as Govt. Poultry Farm, Hariparbath; Instructional Poultry Farm, Faculty of Veterinary Sciences and Animal Husbandry (FVSc \& AH), Shuhama, Srinagar; Division of Veterinary Pathology, FVSc \& AH, Shuhama and private owners of district Ganderbal and Srinagar with a total flock size of 2672 birds. The samples were collected in sterile vials and transported to the lab on ice. 
Isolation and identification of Clostridium perfringens

The samples were inoculated in Difco ${ }^{\mathrm{TM}}$ Cooked meat medium (Becton, Dickinson and Company, Sparks, MD, USA) and incubated anaerobically in 3.5 litre anaerobic jar (Oxoid Limited, Thermo Fisher Scientific Inc., UK) with GasPak ${ }^{\mathrm{TM}}$ Anaerobe Container System (Becton, Dickinson and Company, Sparks, MD, USA) at $37^{\circ} \mathrm{C}$ for 24 hrs. Enriched samples were streaked on Sulphite Polymixin Sulphadiazine agar plates (SPS HiVeg ${ }^{\mathrm{TM}}$ Agar, Modified; Hi-Media laboratories, Mumbai, India) and the plates were incubated anaerobically as above at $37^{\circ} \mathrm{C}$ for $24 \mathrm{hrs}$. Confirmation of the isolates was done by demonstration of the typical cellular morphology in Gram's stained smear, standard biochemical tests and detection of $C$. perfringens by species specific polymerase chain reaction (PCR) using 16S rRNA specific primers.

\section{Extraction of DNA}

The DNA was extracted by boiling method. Briefly, suspected isolated colonies from agar plates were suspended in $1.5 \mathrm{ml}$ microcentrifuge tubes containing $100 \mu \mathrm{l}$ of distilled water by gentle vortexing. The samples were boiled for $5 \mathrm{~min}$, cooled on ice for $10 \mathrm{~min}$ and centrifuged at $10,000 \times \mathrm{g}$ in a table-top microcentrifuge (Cooling Centrifuge, Eppendorf 5418R, Hamburg, Germany) for $10 \mathrm{~min}$. Three microlitres $(\mu \mathrm{l})$ of the supernatant was used as the template for PCR.

Amplification of 16S rRNA gene of Clostridium perfringens by polymerase chain reaction

Isolates of $C$. perfringens were confirmed by amplifying 16S rRNA gene of the $C$. perfringens (Tonooka et al., 2005). The primers used in the experiment have the following sequence: forward-TAACCTGCC TCATAGAGTR and reverse- TTTCACAT CCCACTTAATC. The PCR conditions consisted of initial denaturation at $95^{\circ} \mathrm{C}$ for 15 min, followed by 35 cycles of denaturation at $94^{\circ} \mathrm{C}$ for $30 \mathrm{sec}$, annealing at $49^{\circ} \mathrm{C}$ for $90 \mathrm{sec}$ and extension at $72^{\circ} \mathrm{C}$ for $90 \mathrm{sec}$. This was followed by final extension at $72^{\circ} \mathrm{C}$ for 10 min.

\section{Multiplex Polymerase chain reaction}

All the $C$. perfringens isolates were also screened for six different toxin genes using a multiplex PCR for toxinotyping (van Asten $e t$ al., 2008). These six toxin genes include $\alpha$ toxin $(c p a), \beta$-toxin $(c p b), \varepsilon$-toxin $(e t x), i$ toxin (cpi), $\beta 2$-toxin $(c p b-2)$ and enterotoxin (cpe).

The primers used for the amplification of the genes are shown in Table 1. The PCR conditions consisted of initial denaturation at $95^{\circ} \mathrm{C}$ for $15 \mathrm{~min}$, followed by 35 cycles of denaturation at $94^{\circ} \mathrm{C}$ for $30 \mathrm{sec}$, annealing at $53^{\circ} \mathrm{C}$ for $90 \mathrm{sec}$ and extension at $72^{\circ} \mathrm{C}$ for 90 sec. This was followed by final extension at $72^{\circ} \mathrm{C}$ for $10 \mathrm{~min}$. The MTCC culture of $C$. perfringens type $\mathrm{B}$ was used as positive control, while sterilized distilled water served as negative controls.

All the PCR assays in this study were performed in $25 \mu \mathrm{l}$ reaction volume in thermal cycler (Mastercycler Gradient, Eppendorf AG, Hamburg, Germany).

The reaction consisted of template DNA, 2.5 $\mu 1$ of $10 \mathrm{X}$ buffer, $0.2 \mu \mathrm{l}$ of $25 \mathrm{mM}$ dNTP mix, $1 \mathrm{U}$ of Taq DNA Polymerase (Fermentas Life Sciences), $0.5 \mu 1$ of each forward and reverse primers and sterile distilled water. The $\mathrm{MgCl}_{2}$ was adjusted at $2.0 \mathrm{mM}$ concentration. The primers were procured from GCC Biotech, Kolkata, India. 


\section{Results and Discussion}

All the broiler chickens showed severe depression, decreased appetite, diarrhea, reluctance to move and ruffled feathers prior to death. Post mortem examination showed that birds were dehydrated and had fetid odor. Intestines of affected birds revealed congestion with catarrhal exudate (Fig. 1). Focal necrosis and hemorrhages on the upper surface of liver was also noticed in few chicken. These findings correlate with the reports of detection of $C$. perfringens in poultry (Kerry et al., 2013)

Out of 217 samples of chicken, 66 (19 from live birds and 47 from postmortem carcass) harboured the $C$. perfringens. The fecal and morbid samples after overnight incubation in cooked meat medium, showed turbidity and pink colouration of the meat pieces. On Sulphite Polymixin Sulphadiazine (SPS) agar C. perfringens colonies were typically black pigmented or creamish in colour (Fig. 2). On Gram's staining the black colonies isolated on SPS agar appeared typically Gram-positive rods forming subterminal endospores suggestive of $C$. perfringens (Fig. 3). All the isolates produced stormy fermentation, coagulation in litmus milk, showed lecithinase activity on egg yolk agar plates and fermented glucose and lactose. On sheep blood bacterial colonies were found small dew drop like colonies surrounded by an inner zone of complete haemolysis and an outer zone of incomplete haemolysis (Fig. 4). All the 66 isolates which were morphologically and biochemically identified as $C$. perfringens, were also confirmed by $16 \mathrm{~S}$ rRNA gene specific PCR (Fig. 5). Among 66 isolates, 29 were from organised sector and 37 from unorganised sector (Table 2). All the 66 isolates were found to possess cpa gene alone as a major toxin gene, thus were designated as toxinotype A. Thirteen of the isolates also carried beta2 toxin gene $(c p b 2)$
(Fig. 6). None of the isolates carried $c p b$, etx or cpi genes indicating the absence of $C$. perfringens toxinotype $\mathrm{B}, \mathrm{C}, \mathrm{D}$ or $\mathrm{E}$ in chicken samples. The findings are in agreement with other workers from different parts of the world who reported isolation of $C$. perfringens type A from chicken (Nauerby et al., 2003; Baums et al., 2004; Malmarugan et al., 2012; Park et al., 2015). Gholamiandekhordi et al., (2006) detected $\beta 2$ toxin gene in five out of 63 isolates from poultry flocks with different disease conditions and suggested that the $\beta 2$ toxin is not an important or essential virulence factor in the development of disease in poultry. Similarly, $c p b 2$ gene was detected in $C$. perfringens type $\mathrm{A}$ isolates from commercial broiler chickens and parent broiler breeder hens in Ezypt (Osman et al., 2012) and from native fowl suffering from necrotic enteritis in India (Thomas et al., 2014). In the present study, none of the isolates carried cpe-gene which is in agreement with the finding of other workers (Engstrom et al., 2003, Heikinheimo and Korkeala, 2005). Recently, it was speculated that $c p b 2$ positive $C$. perfringens may cause focal duodenal necrosis in egg-laying chickens (França et al., 2016). For a long time, alpha toxin was proposed to be the main virulence factor for necrotic enteritis in poultry, although the normal broiler microbiota and outbreak strains of $C$. perfringens were type A. (Nauerby et al., 2003; Gholamiandehkordi et al., 2006). In the recent past, a novel toxin called necrotic enteritis B-like toxin (NetB) was described that were associated with necrotic enteritis in broilers (Keyburn et al., 2008). However, we did not detect the toxin in our study. On the other hand, netB-negative isolates from birds suffering from necrotic enteritis may indicate that other, yet to be determined, virulence factors are produced by these strains. However, net $B$-negative strains do not induce necrotic enteritis in experimental bird models. 
Fig.1 Congestion with catarrhal exudate in small intestines

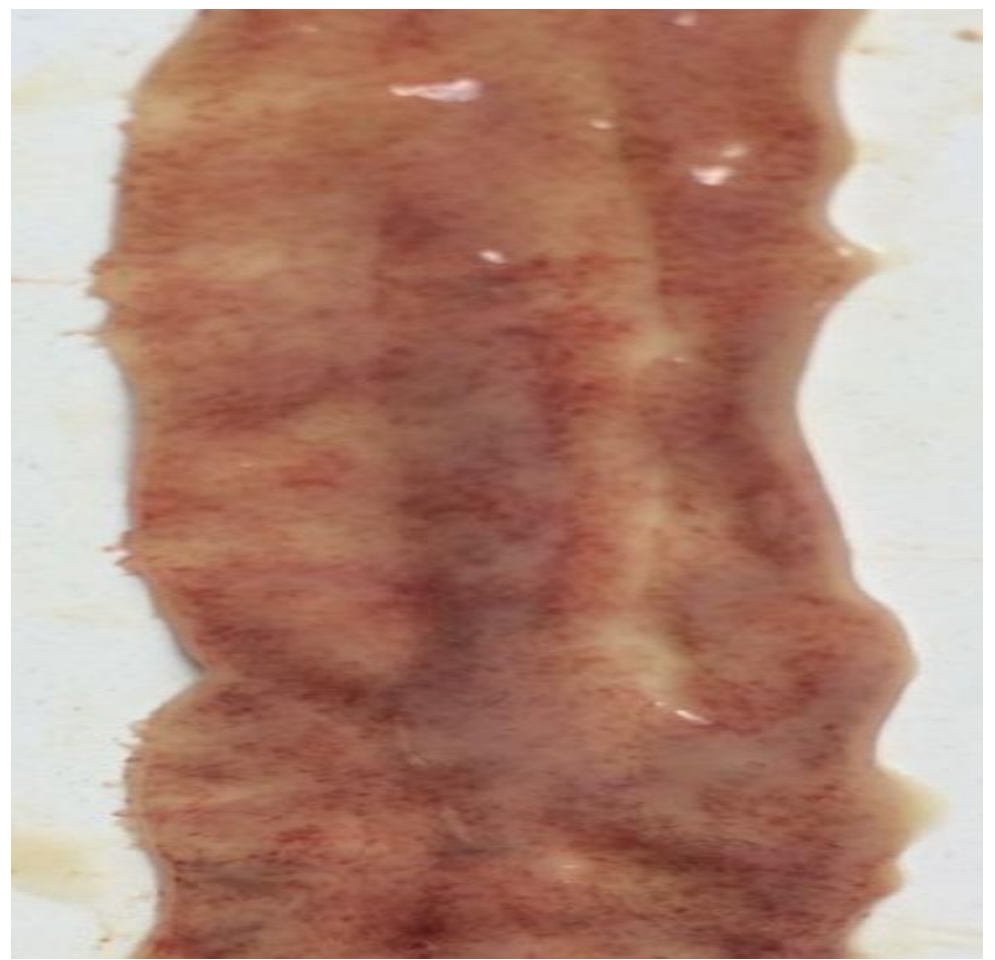

Fig.2 Culture of Clostridium perfringens on Sulphite Polmixin Sulphadiazine (SPS) agar medium showing black and cream colonies

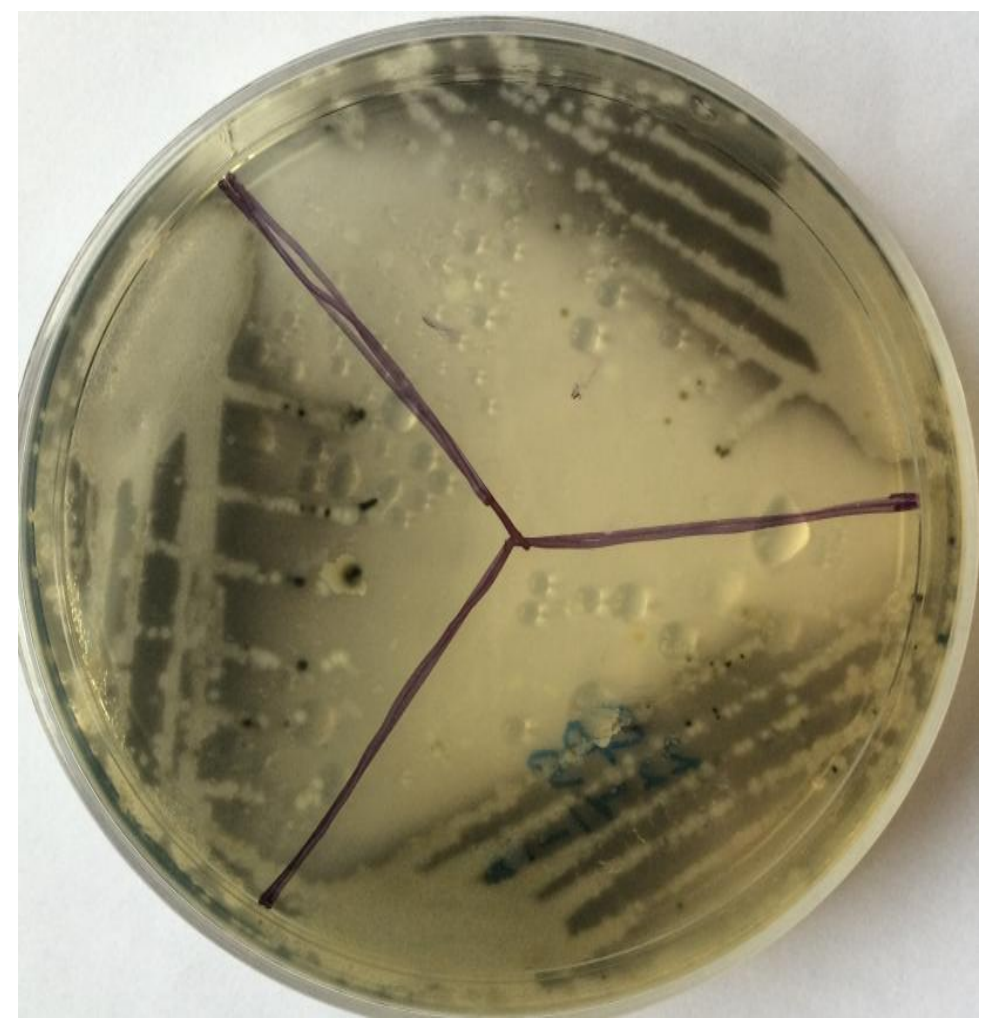


Fig.3 Gram stained smear of Clostridium perfringens showing Gram positive violet rods under oil immersion

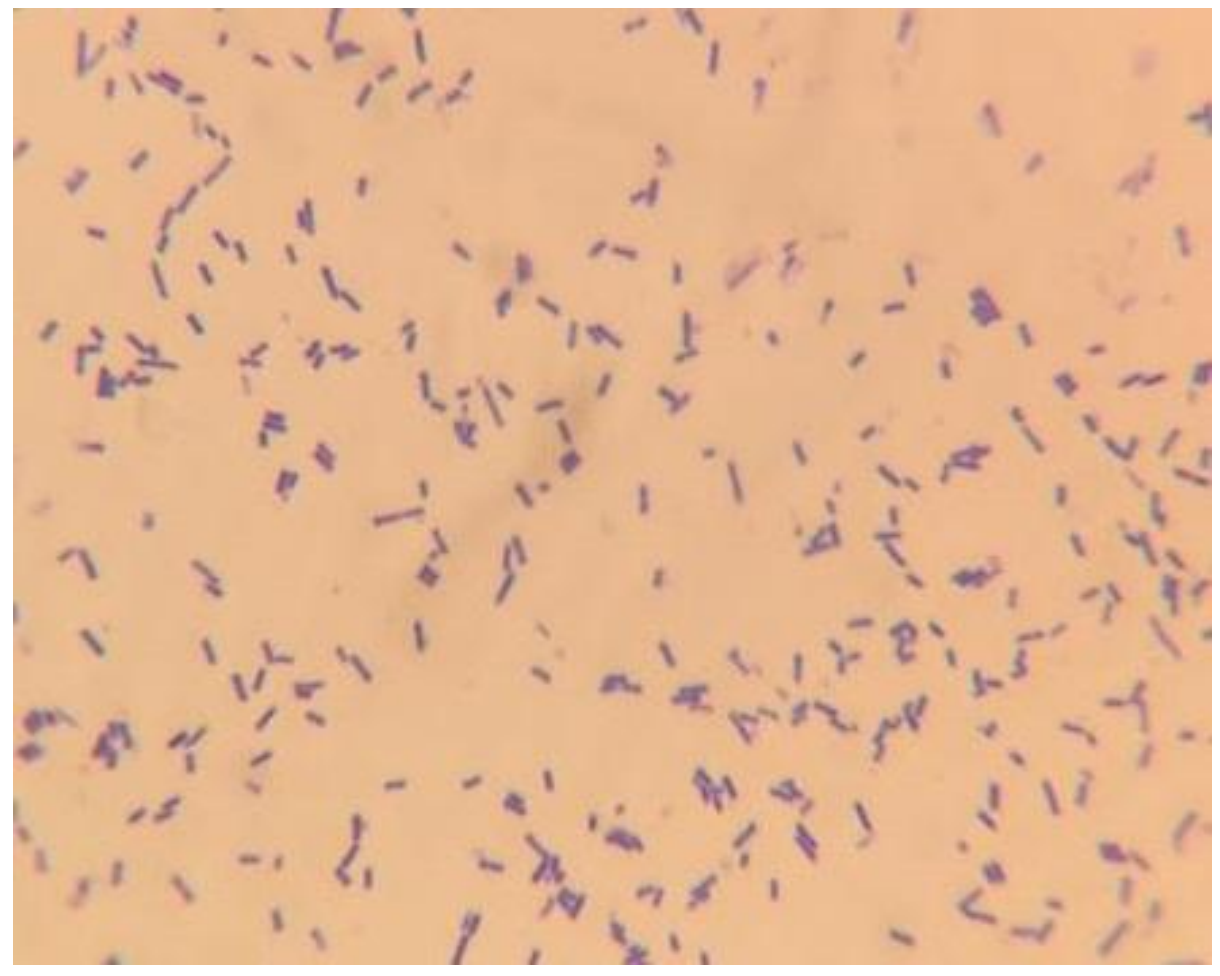

Fig.4 Double zone of hemolysis produced by Clostridium perfringens on sheep blood agar

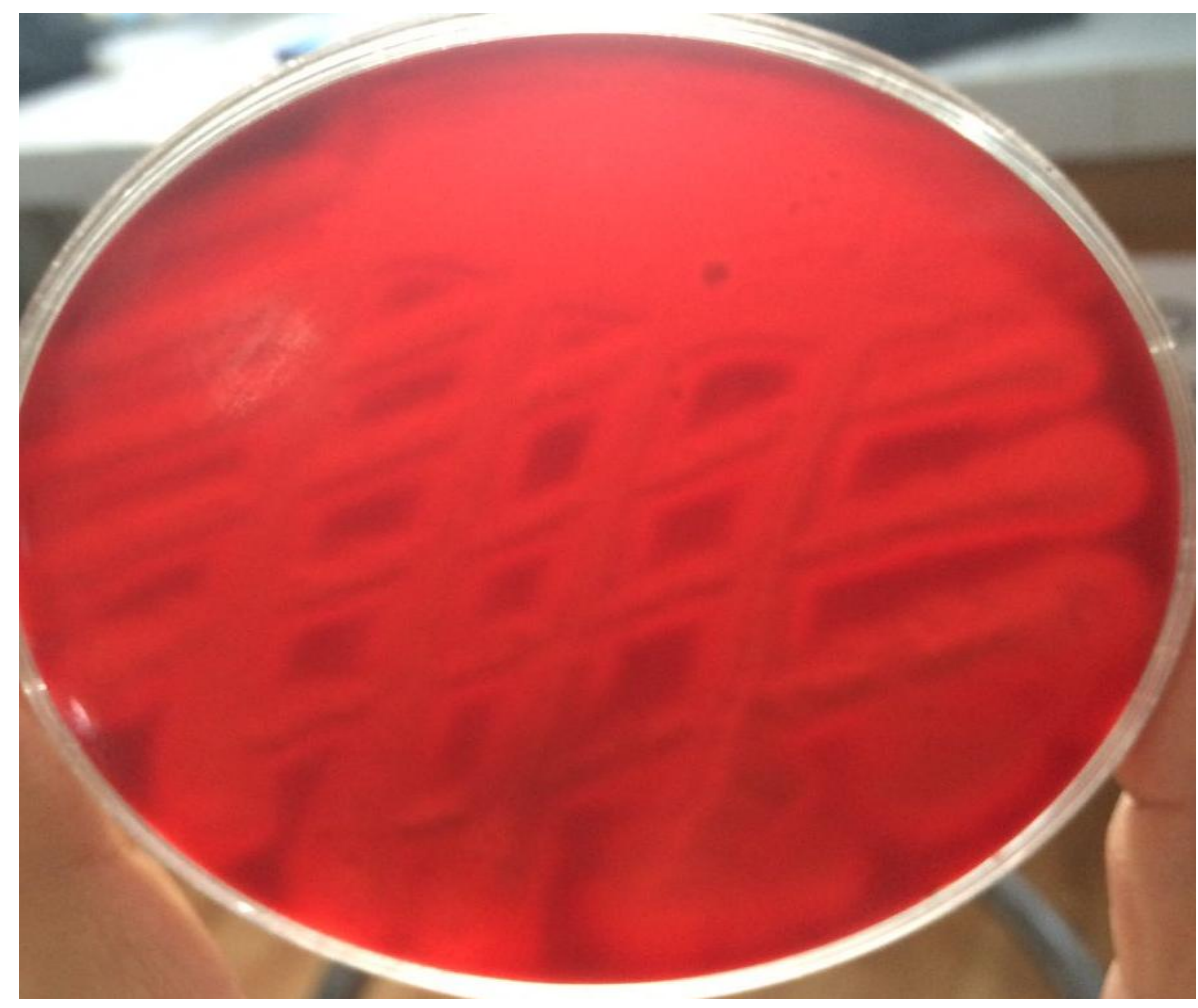


Fig.5 Agarose gel electrophoresis showing $481 \mathrm{bp}$ amplicon of 16SrRNA gene of Clostridium perfringens Lane M : 100 bp ladder, Lane 1: Negative control, Lane 2: Positive control, Lane 3 \& 4: $C$. perfringens with amplified 16SrRNA gene

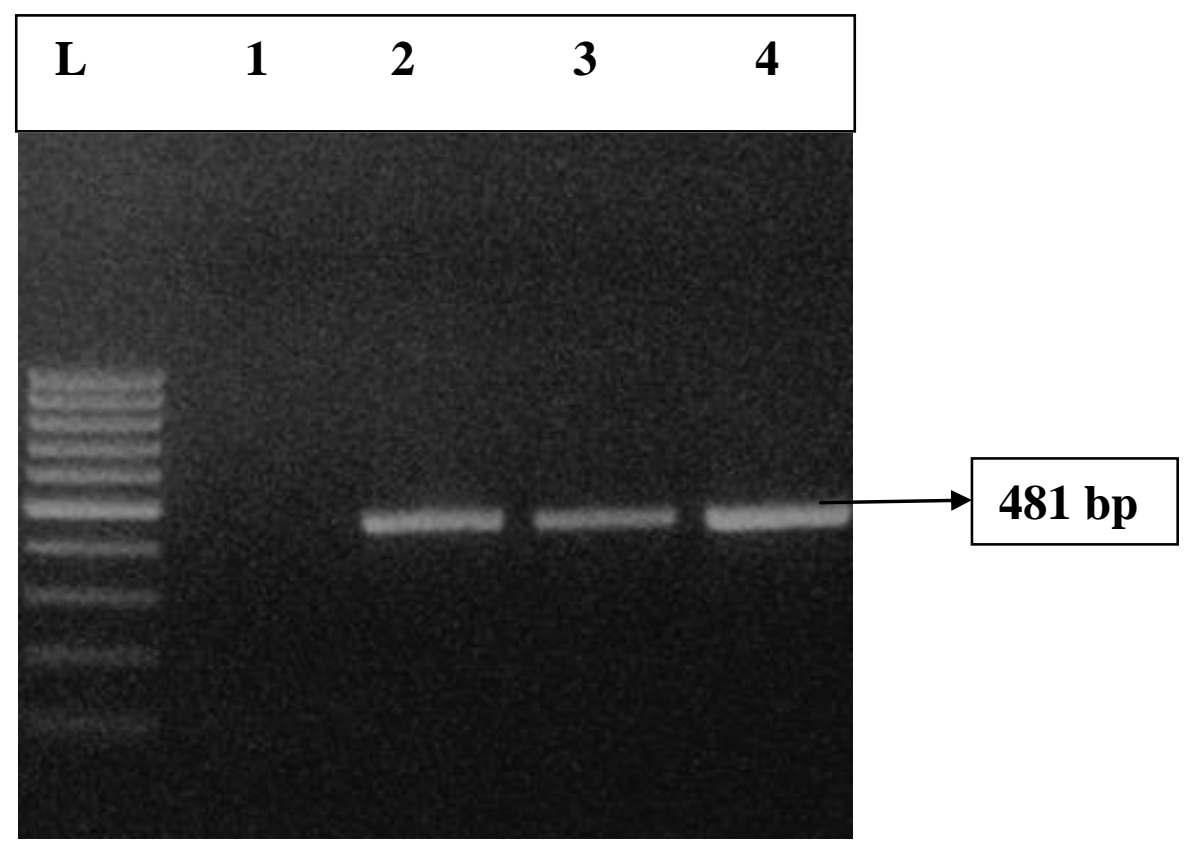

Fig.6 Agarose gel electrophoresis of multiplex PCR amplicons of different virulence genes of Clostridium perfringens. Lane M: 100 bp ladder, Lane 1: Positive control, Lane 2: Negative control, Lane 3: C. perfringens Type A with amplified cpa (324 bp) and beta 2 (548 bp) genes, Lane 4: $C$. perfringens Type A with amplified cpa (324 bp) gene

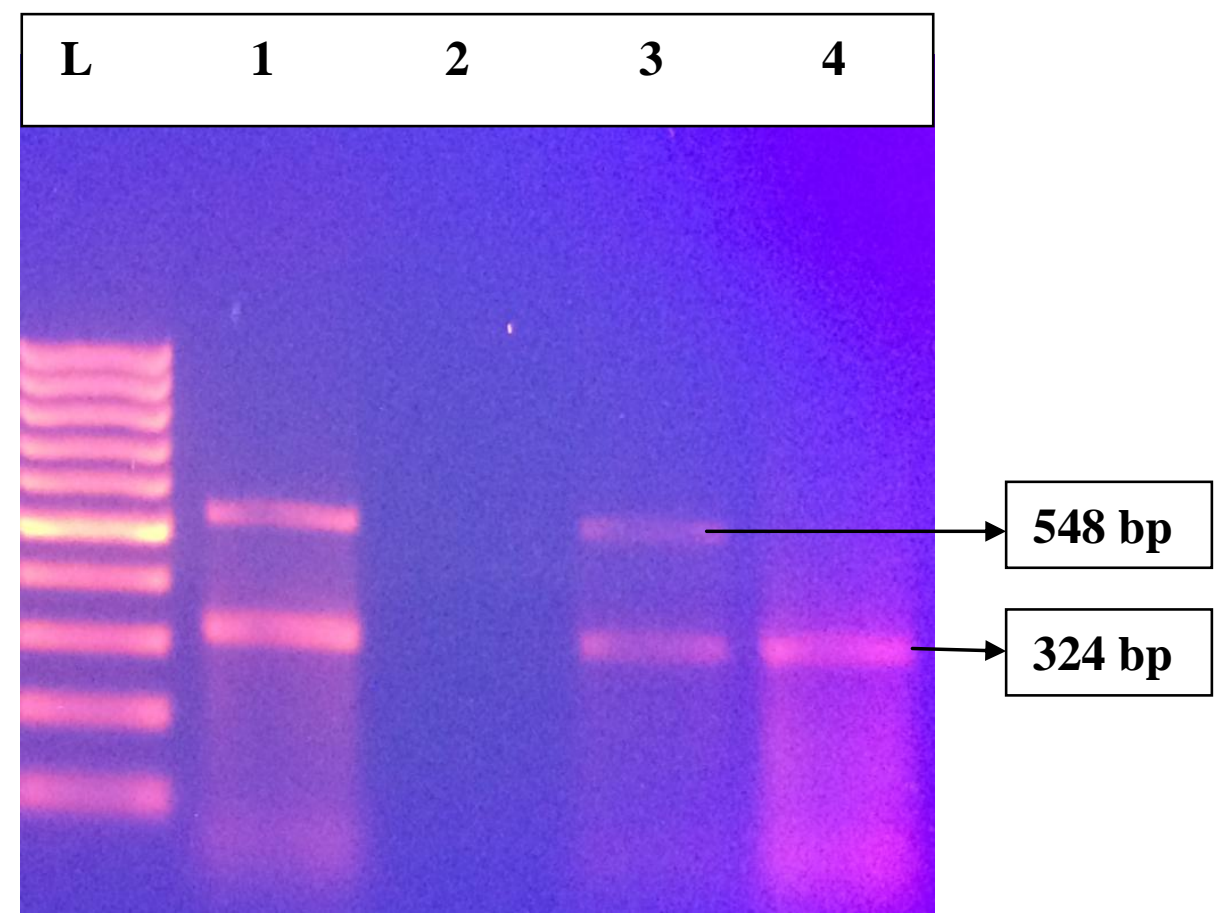


Table.1 List of primers used for toxinotyping

\begin{tabular}{|c|c|c|c|c|c|}
\hline Primers & Primer Sequences $\left(5^{\prime}-3^{\prime}\right)$ & $\begin{array}{l}\text { Target } \\
\text { gene }\end{array}$ & $\begin{array}{l}\text { Primer } \\
\text { conc. }(\mu \mathrm{M} \\
\text { each) }\end{array}$ & $\begin{array}{l}\text { Product } \\
\text { size (bp) }\end{array}$ & Reference \\
\hline Cpa-F & GCTAATGTTACTGCCGTTGA & \multirow{2}{*}{ Сра } & \multirow{2}{*}{0.4} & \multirow{2}{*}{324} & \multirow{12}{*}{$\begin{array}{l}\text { van Asten et } \\
\text { al., (2008) }\end{array}$} \\
\hline Cpa-R & CCTCTGATACATCGTGTAAG & & & & \\
\hline Cpb-F & GCGAATATGCTGAATCATCA & \multirow{2}{*}{$C p b$} & \multirow{2}{*}{0.4} & \multirow{2}{*}{195} & \\
\hline Cpb-R & GCAGGAACATTAGTATATCTTC & & & & \\
\hline Etx-F & TGGGAACTTCGATACAAGCA & \multirow{2}{*}{ Etx } & \multirow{2}{*}{0.4} & \multirow{2}{*}{376} & \\
\hline Etx-R & AACTGCACTATAATTTCCTTTTCC & & & & \\
\hline Cpi-F & AATGGTCCTTTAAATAATCC & \multirow{2}{*}{ Cpi } & \multirow{2}{*}{0.4} & \multirow[b]{2}{*}{272} & \\
\hline Cpi-R & TTAGCAAATGCACTCATATT & & & & \\
\hline cpb2-F & AAATATGATCCTAACCAACAA & \multirow{2}{*}{$c p b 2$} & \multirow{2}{*}{0.4} & \multirow{2}{*}{548} & \\
\hline cpb2-R & CCAAATACTCTAATYGATGC & & & & \\
\hline Cpe-F & TTCAGTTGGATTTACTTCTG & \multirow{2}{*}{ Cpe } & \multirow{2}{*}{0.4} & \multirow{2}{*}{485} & \\
\hline Cpe-R & TGTCCAGTAGCTGTAATTGT & & & & \\
\hline
\end{tabular}

Table.2 Occurrence of Clostridium perfringens toxinotypes in chicken under organized and unorganized rearing condition

\begin{tabular}{|l|l|l|l|l|l|}
\hline S No. & Source & $\begin{array}{l}\text { No of } \\
\text { samples } \\
\text { tested }\end{array}$ & $\begin{array}{l}\text { No of samples } \\
\text { positive for } \\
\text { C.perfringens }\end{array}$ & Toxinotype & $\begin{array}{l}\text { Occurrence of } \\
\text { C. perfringens } \\
(\boldsymbol{\%})\end{array}$ \\
\hline 1 & Private sector & 131 & 37 & A & 28.24 \\
\hline 2 & Govt. sector & 86 & 29 & A & 33.72 \\
\hline & Total & 217 & 66 & & 30.41 \\
\hline
\end{tabular}

Table.3 Age wise distribution of Clostridium perfringens in chickens

\begin{tabular}{|c|c|c|}
\hline Age group & No. of samples & No. Positive \\
\hline 2-6 weeks & 141 & $47(33.33 \%)$ \\
\hline$>6$ weeks & 76 & $19(25 \%)$ \\
\hline
\end{tabular}

The rate of isolation was more $(33.33 \%)$ from broilers of 2 to $6 \mathrm{wk}$ of age than older birds (25\%) (Table 3). This is in agreement with Lovland and Kaldhusdal (2001), who reported detection of C. perfringens in 2-6 wk broiler chickens. Furthermore, $C$. perfringens is auxotrophic for 13 amino acids (Myers et al., 2006) and an increase in available nutrients would thus allow $C$. perfringens to proliferate extensively, leading to increased intestinal toxin levels. Thus, predisposing factors are important, but it is also essential that poultry pathogenic strains should be present to induce the disease (Timbermont et al., 2011).

\section{Acknowledgement}

The authors are thankful to Indian Council of Agricultural Research, New Delhi for the facilities under the Niche Area of Excellence on Anaerobic Bacteria project entitled "Study of Clostridium perfringens and Dichelobacter nodosus (Anaerobic Bacteriology)." The DST INSPIRE Fellowship awarded to me to carry 
out the $\mathrm{PhD}$ research is also gratefully acknowledged here.

\section{References}

Al-Sheikhly, F. and Truscott, R.B. 1977a. The interaction of Clostridium perfringens and its toxins in the production of necrotic enteritis of chickens. Avian Diseases 21: 256-63.

Al-Sheikhly, F. and Truscott, R.B. 1977b. The pathology of necrotic enteritis of chickens following infusion of crude toxins of Clostridium perfringens into the duodenum. Avian Diseases 21: 24155.

Asaoka, Y., Yanai, T., Hirayama, H., Une, Y., Saito, E., Sakai, H., Goryo, M., Fukushi, H. and Masegi, T. 2004. Fatal necrotic enteritis associated with Clostridium perfringens in wild crows (Corvus macrorhynchos). Avian Pathology 33: 19-24.

Baums C G, Schotte U, Amtsberg G and Goethe R. 2004. Diagnostic multiplex PCR for toxin genotyping of Clostridium perfringens isolates. Veterinary Microbiology 100: 11-16.

Craven, S.E., Stern, N.J., Bailey, J.S. and Cox, N.A. 2001. Incidence of Clostridium perfringens in broiler chickens and their environment during production and processing. Avian Diseases 45: 887-896. 21

Dahiya, J.P., Wilkie, D.C., Van Kessel, A.G. and Drew, M.D. 2006. Potential strategies for controlling necrotic enteritis in broiler chickens in postantibiotic era. Animal Feed Science and Technology. 129: 60-88.

Engstrom, B.E., Fermer, C., Lindberg, A., Saarinen, E., Baverud, V. and Gunnarsson, A. 2003. Molecular typing of isolates of Clostridium perfringens from healthy and diseased poultry. Veterinary Microbiology 94: 225-235.
Ficken, M.D. and Wages, D.P. 1997. Diseases of Poultry. Mosby-Wolfe. Ames, Iowa, USA. 261-264 pp.

França M, Barrios M A, Stabler L, Zavala G, Shivaprasad H L, Lee M D, Villegas A $\mathrm{M}$ and Uzal F A. 2016. Association of beta2-positive Clostridium perfringens type A with focal duodenal necrosis in egg-laying chickens in the United States. Avian Diseases 60: 43-49.

Gholamiandekhordi A R, Ducatelle R, Heyndrickx M, Haesebrouck F and Van Immerseel F. 2006. Molecular and phenotypical characterization of Clostridium perfringens isolates from poultry flocks with different disease status. Veterinary Microbiology 113: 143-152.

Heikinheimo A and Korkeala H. 2005. Multiplex PCR assay for toxin typing Clostridium perfringens isolates obtained from Finnish broiler chickens. Letters in Applied Microbiology 40: 407-411.

Helmbold and Bryant. 1971. Pathology of Necrotic Enteritis in Domestic Fowl. Avian Diseases 15: 775-780.

Hofshagen, M. and Stenwig, H. 1992. Toxin production by Clostridium perfringens isolated from broiler chickens and capercaillies (Tetrao urogallus) with and without necrotizing enteritis. Avian Diseases 36: 837-43. 23

Johansson, A., Aspan, A., Bagge, E., Båverud, V., Engström, B.E. and Johansson, K. 2006. Genetic diversity of Clostridium perfringens type A isolates from animals, food poisoning outbreaks and sludge. BMC Microbiology, 6:47.

Kaldhusdal, M. and Hofshagen, M. 1992. Barley inclusion and avoparcin supplementation in broiler diets. 2 . Clinical, pathological, and bacteriological findings in a mild form of necrotic enteritis. Poultry Science 71: 
1145-1153.

Kerry K. Cooper, J. Glenn Songer, Francisco A. Uzal 2013 Diagnosing clostridial enteric disease in poultry. Journal of Veterinary Diagnostic Investigation 25(3) 314- 327

Keyburn, A.L., Boyce, J.D., Vaz, P., Banam, T.L., Ford., M.E., Parker, D., Rood, J.I. and Moore, R.J. 2008. Net B, a new toxin that is associated with avian necrotic enteritis caused by Clostridium perfringens. PLoS Pathology 4:26-28.

Kwon, Y.K., Lee, Y.J. and Mo, I.P. 2004. An outbreak of necrotic enteritis in the ostrich farm in Korea. Journal of Veterinary Medical Science 66: 1613-5.

Long, J.R., Pettit, J.R. and Barnum, D.A. 1974. Necrotic enteritis in broiler chickens. II. Pathology and proposed pathogenesis. Canadian Journal of Comparative Medicine 38: 467-74.

Lovland A and Kaldhusdal M. 2001. Severely impaired production performance in broiler flocks with high incidence of Clostridium perfringens-associated hepatitis. Avian Pathology 30:73-81.

Malmarugan S, Boobalan A and Dorairajan N. 2012. Necrotic Enteritis in broiler and layer farms in Tamil Nadu, India. International Journal for Agro Veterinary and Medical Sciences 4: 241-249.

McDevitt, R.M., Brooker, J.D., Acamovic, T. and Sparks, N.H.C. 2006. Necrotic enteritis; a continuing challenge for the poultry industry. World's Poultry Science Journal 62(2): 221-247.

Myers, G.S.A., Rasko, D.A., Cheung, J.K., Ravel, J., Seshadri, R., DeBoy, R.T., et al., 2006. Skewed genomic variability in strains of the toxigenic bacterial pathogen, Clostridium perfringens. Genome Research. 16, 1031-1040.

Nauerby, B., Pedersen, K. and Madsen, M. 2003. Analysis by pulsed-field gel electrophoresis of the genetic diversity among Clostridium perfringens isolates from chickens. Veterinary Microbiology 94: 257-266.

Osman K M, Soliman Y A, Amin Z M S and Aly M A K. 2012. Prevalence of Clostridium perfringens type A isolates in commercial broiler chickens and parent broiler breeder hens in Egypt. Revue Scientifique et Technique (International Office of Epizootics) 31: 931-941.

Park J Y, Kim S, Oh J Y, Kim H R, Jang I, Lee H S and Kwon Y K. 2015. Characterization of Clostridium perfringens isolates obtained from 2010 to 2012 from chickens with necrotic enteritis in Korea. Poultry Science 94:1158-1164.

Thomas P, Arun T E, Karthik K, Berin P V, Kumar M A, Singh N, Usharani J, Palanivelu M, Gupta S K, Dhama K and Yiswas K N. 2014. Molecular characterization and toxinotyping of a Clostridium perfringens isolate from a case of necrotic enteritis in Indian Kadaknath fowl. Asian Journal of Animal and Veterinary Advances 9: 385-394.

Timbermont L, Haesebrouck F, Ducatelle, R. and van Immerseel F. 2011. Necrotic enteritis in broilers: an updated review on the pathogenesis. Avian Pathology. 40:341-347

Timbermont, L., Lanckriet, A., Dewulf, J., Nollet, N., Schwarzer, K., Haesebrouck, F., Ducatelle, R. and Van Immerseel, F. 2010. Control of Clostridium perfringens induced necrotic enteritis in broilers by target released butyric acid, fatty acids and essential oils. Avian Pathology 39: 117-121.

Tonooka T, Sakata S, Kitahara M, Hanai M, Ishizeki S, Takada M, Sakamoto M, Benno Y. 2005. Detection and quantification of four species of the genus Clostridium in infant feces. 
Microbiological Immunology 49:987992.

Van Asten A J A M, Wiel C W, Van Nikolaou G, Houvers D J and Grone A. 2008. A multiplex PCR for toxin typing of Clostridium perfringens. Veterinary Microbiology 136: 411-412.

Williams, R.B., Marshall, R.N., La Ragione, R.M. and Catchpole, J. 2003. A new method for the experimental production of necrotic enteritis and its use for studies on the relationships between necrotic enteritis, coccidiosis and anticoccidial vaccination of chickens. Parasitology Research 90: 19-26.

Wobeser, G. and Rainnie, D.J. 1987. Epizootic necrotic enteritis in wild geese. Journal of Wildlife Diseases 23: 376-85.

\section{How to cite this article:}

Nyrah, Q., S.A. Wani, N. Nazir, S. Rasool, Q. Beigh, Z.A. Kashoo, I. Hussain, Sabia Qureshi and Ali, R. 2017. Clostridium perfringens Type A from Broiler Chicken with Necrotic Enteritis in Kashmir Valley, India. Int.J.Curr.Microbiol.App.Sci. 6(12): 2443-2453. doi: https://doi.org/10.20546/ijcmas.2017.612.283 